\title{
MICROGLIAL ADIPOBIOLOGY: A NEW CONCEPT FOR UNDERSTANDING THE ADIPOSE TISSUE-BRAIN CROSSTALK IN HEALTH AND DISEASE
}

\author{
Marin D. Zhelezov* \\ Department of Anatomy and Cell Biology, Medical University, Varna, Bulgaria
}

\begin{abstract}
This article proposes the concept of "microglial adipobiology" as a new theoretical framework for the crosstalk between the adipose tissue and the central nervous system in health and disease. It reviews an important mechanistic link, explaining the neuropsychiatric complications of obesity, including the role of adipose-secreted signaling proteins (adipokines) and adipose-derived stem cells in influencing microglial function and neuroinflammation. An increasing body of evidence suggests that neuroinflammation mediated by microglia, macrophage-like cells in the brain, plays a contributory role in the pathogenesis of various neurodegenerative diseases. The specific positive and negative effects of the major types of dietary fats are also discussed in the case of obesogenic and ketogenic diets. Furthermore, it explores the effects of microglial cells on adipose tissue via modulating the central control of energy homeostasis in the hypothalamus and proposes the concept of "transgenerational adipobiology" as a framework explaining the neurological and metabolic complications of the offspring of obese mothers. Finally, potential directions for future therapeutic interventions are considered.
\end{abstract}

Adipobiology 2019;10:25-40

Keywords: adipobiology, adipose tissue, adipokines, brain, disease, microglia, neuroinflammation, obesity

Received 24 May 2019, revised 19 June 2019, accepted 20 June 2019.

*Correspondence: Dr Marin D. Zhelezov. Department of Anatomy and Cell Biology, Medical University, BG-9002 Varna, Bulgaria. E-mail: dr.marin.zhelezov@gmail.com

\section{Introduction}

The modern obesity epidemic is associated with significantly increased comorbidity with a variety of other conditions (1), including neurological and psychiatric disease (2). These associations, together with the concurrent mental health crisis (3), raise the question on how does the adipose tissue influence the brain and the pathobiology of neurological disease. Recent studies in adipobiology have shifted the view of adipose tissue as a mere fat-storage depot to a complex endo- and paracrine organ, that can affect systemic physiology and contribute to the pathogenesis of disease $(4,5)$. Importantly, links have been shown how the adipose tissue can affect the brain in both health and disease $(6,7)$.

Inflammation of the central nervous system (CNS), termed "neuroinflammation", is currently considered a key mechanism in the pathogenesis of both neurologic and psychiatric conditions (8). A main player in neuroinflammation are microglia, the brain's resident phagocytic cells, which due to their extensive and complex involvement in virtually all CNS conditions are considered 
"central players" in brain disease (9).

Could the adipose tissue affect the brain via influencing microglial cells either directly or indirectly? The present article reviews the accumulating evidence from both correlational and experimental studies that support this notion, focusing on how microglial function can be altered via the contents of an obesogenic diet and signaling proteins (collectively designated adipokines) secreted from adipose cells, as well as, how, in turn, microglial cells can modulate the central control over feeding behavior and energy homeostasis, thus influencing the adipose tissue. Given these findings, we can propose the concept of "microglial adipobiology", establishing the bidirectional adiposemicroglial crosstalk as a new theoretical framework, linking the pathobiology of obesity and related neuropsychiatric diseases (see also 10).

\section{Obesity and brain disorders: two linked pandemics}

Obesity is a major global health concern, affecting more than $35 \%$ of people in the USA (11) and more than 600 million adults worldwide (12). Around $60 \%$ of the world's population will reach critical body mass index (BMI) values by 2030 (13). Importantly, obesity is not merely an accumulation of excessive body fat but, rather, a complex systemic pathological state than has been linked with increased risk of several medical conditions, including diabetes (14), hypertension (15), cardiovascular disease, stroke, and even certain cancers (16).

Mounting evidence has shown an association between obesity and cognitive problems. Obese people have diminished cognitive functions on a variety of measures (17-20), including impaired executive functions $(18,19)$. Obesity is associated with reduced brain volume (23), including in key areas for cognition such as the hippocampus (24). Obesity is also linked with cognitive impairments in old age (25) and is considered a risk factor for dementia and Alzheimer's disease $(23,24)$. The link between obesity and the brain is especially important, given that the prevalence of mood disorders has increased significantly in the West $(28,29)$ to a point where, today, one in five people meet criteria for a common mental disorder (30).

Mental illness is considered the pandemic of the 21st century and the next global health challenge (3). Indeed, obesity has also been associated with psychiatric conditions like depression and anxiety (31-35). There is even evidence that our modern diet may be a key contributing factor to mental health $(36,37)$, hence, the field of "nutritional psychiatry" has been established (38). The association between the two big modern pandemics, obesity and mental illness, raises the need to investigate for possible mechanistic links between the two.

\section{Inflammation as a common mechanism in obesity and brain disease}

Accumulating evidence in the past two decades has resulted in several paradigm shifts (5), challenging the classic view of adipose tissue as a mere lipid storage. Currently, adipose tissue is considered a dynamic endocrine and paracrine organ producing over 600 signaling proteins collectively designated adipokines (4, 7,39 ). Adipokines have been shown to possess a dazzling array of biological functions, including control over feeding behavior, energy homeostasis, inflammation, immunity, cognition, insulin resistance and the pathogenesis of cardiometabolic and other diseases $(4,6,40,41)$. Since many adipokines have effects in the CNS and can ultimately contribute to the regulation of cognition and behavior, the field of neuroadipocrinology has emerged emerged and the adipose tissue has been considered as "a third brain" $(5,6)$.

Obesity is not a mere accumulation of the adipose tissue, but is associated with chronic systemic low-grade inflammation due to infiltration and activation of macrophages in adipose tissue. As a consequence, the adipose tissue in obesity is marked by increased secretion of pro-inflammatory adipokines (42) and reduced secretion of anti-inflammatory and metabotrophic ones such as adiponectin (42), nerve growth factor (NGF) and brain-derived neurotrophic factor (BDNF) $(10,43)$. This leads to increased levels of inflammatory markers in the serum and multiple metabolically active peripheral tissues and organs, including the brain (44-47). This type of inflammation is considered atypical due to the lack of Galenus' signs such as rubor et tumor cum calore et dolore (redness, swelling, heat and pain), which usually are associated with an immune response $(48,49)$.

On a similar note, the classical neuron-centered views of CNS disease have been challenged with accumulating evidence on the involvement of the immune system in brain pathology (50). Nowadays, inflammation of the nervous system ("neuroinflammation") is considered a leading mechanism in the pathogenesis of CNS conditions, including Alzheimer's and Parkinson disease, stroke, traumatic brain injury, as well as mood disorders (50-53). With respect to the latter, significantly elevated levels of all major kinds of cytokines were detected in blood samples from patients with depression, anxiety, bipolar, and obsessivecompulsive- and posttraumatic stress disorder, schizophrenia, and autism (8). Major molecules involved include soluble interleukin receptors, interleukin antagonists, tumor necrosis factoralpha (TNF- $\alpha$ ), soluble TNF receptor, IFN- $\gamma$, chemokines, and matrix metalloproteinases (MMP) (8). Under experimental conditions, animals injected with proinflammatory cytokines like TNF- $\alpha$ have been shown to exhibit sickness behavior in a dose- and time-related manner (54). 


\section{Microglia are central players in brain disease}

An increasing body of evidence suggests that neuroinflammation mediated by microglia play an important role in the pathobiology of various neurodegenerative diseases. Microglia, the resident phagocytic cells in the brain, are a part of the glial system of non-neuronal elements in the CNS and account for around $10 \%$ of all cells in the brain (55). During development, microglia arise from erythromyeloid precursors in the yolk sac which migrate and colonize the embryonic brain (56-60). Under physiological conditions, microglia possess numerous highly-branched elongated fine processes (61), which they use to actively survey their cell-specific territory, monitoring the CNS environment for infection or injury.

Accumulating evidence in recent years has revealed crucial microglial functions beyond the immune response to pathology, namely, involvement in the regulation of cognitive processes like learning and memory. During development, microglia regulate neurogenesis, as well as synaptogenesis and neural network formation $(62,63)$. Postnatally, they have been shown to contact presynaptic and postsynaptic neuronal elements and contribute to synapse regulation, including synaptogenesis and pruning (64, 65). Microglia monitor neuronal activity and neurotransmitter release $(66,67)$, especially in the context of sensory deprivation and stimulation, as well as specific learning and memory tasks $(68,69)$.

Under pathological conditions, microglia "activate" and undergo a series of changes, including adopting an amoeboid morphology with enlargement of the soma and shortening and thickening of primary processes, moving toward the site of injury, increased proliferation and phagocytic ability, as well as secretion of pro-inflammatory molecules (70).

However, microglial activation has implications beyond normal immunological defense and can become neurotoxic (71, 72). Disruptions in neuronal networks during development due to perturbations in synaptic pruning and modification by microglia has been linked to diseases such as autism and schizophrenia (73). A staggering amount of evidence has elucidated multiple mechanisms of microglial involvement in conditions such as Alzheimer's disease, amyotrophic lateral sclerosis, multiple sclerosis, glaucoma, and neuropathic pain $(9,74)$. As key players in neuroinflammation, microglia have been associated with virtually all neurological conditions (75) and are now considered "central players" in brain disease (9).

It should be noted that, although, ramified microglia have been classically termed "resting", however, this is confusing and does not reflect their physiological roles. Indeed, with the growing body of evidence about the physiological effects of ramified microglia, they have been termed "never resting" (76). By "rest- ing" it should be understood not a lack of activity but, rather, a current lack of involvement in neuroinflammation. Thus, analyzing microglial morphology is a way to assess their activation during neuroinflammation. Ramified cells are correlated with anti-inflammatory processes (77) while amoeboid cells are associated with CNS inflammation or injury (78-80).

\section{Peripheral inflammation can activate microglia and inflame the brain}

It is well established that peripheral inflammation can reach the brain, activate microglia $(54,81)$ and contribute to the pathogenesis of neurological and psychiatric disorders (51). Among commonly studied markers contributing to this process are the pro-inflammatory cytokines IL-1 $\beta$, TNF- $\alpha$, and IL-6 (51). These molecules can reach the brain via several routes (51). They can enter in areas of the CNS missing blood-brain barrier (BBB) such as the circumventricular organs, choroid plexus, and parts of the hypothalamus $(82,83)$. The $\mathrm{BBB}$ itself is made leaky by pro-inflammatory cytokines, including TNF- $\alpha$, and in turn, becomes permeable to them (84). Moreover, these molecules can enter the brain via the vagus nerve projecting to the nucleus of the solitary tract which is connected with the hypothalamus and amygdala (85). Given that inflammatory cytokines in the periphery can stimulate microglia and cause neuroinflammation and that obesity is associated with a systemic inflammatory state, the logical question arises about the possibility of microglia mediating the obesity-associated neurological and cognitive damage.

One possible mechanism, by which microglial cells can impact cognition in obesity is dysregulation of synaptic plasticity. In rats, obesity leads to cognitive deficits, accompanied with changes in microglial morphology and synapse loss in the medial prefrontal cortex (86). It has also been shown that microglia from obese mice are activated and internalize synaptosomes at higher rates compared to non-obese controls (87). However, it is not clear which process comes first: does obesity itself damage synapses which are then phagocytosed by microglia, or does obesity activate microglia which, in turn, engulf otherwise functional synapses (46). Several studies have attempted to address this question.

Cope et al have demonstrated that partial knockdown of the fractalkine receptor prevented both microglial activation and cognitive decline in diet-induced obesity in male rats. Moreover, pharmacological inhibition of microglial activation prevented dendritic spine loss and cognitive degradation. Obesity-associated cognitive decline was ameliorated via pharmacological blockade of microglial phagocytosis (46). Hao et al have demonstrated that dietary obesity reversibly induces synaptic stripping 
by microglia and impairs hippocampal plasticity. Interestingly, only a partial attenuation of obesity via diet-reversal was needed for a complete normalization of hippocampal function and the spatial relationships between microglia and synapses, showing a non-linear relationship between total body adiposity and neuroinflammation (87).

Of particular interest are the inflammatory changes in the brain's center of metabolic control, the hypothalamus, especially the arcuate nucleus of the mediobasal hypothalamus (MBH). Due to its leaky BBB, this nucleus serves as a sensor of circulating signals, allowing direct microglial exposure to blood-borne molecules $(88,89)$. De Souza et al were the first to show an association between diet-induced obesity and hypothalamic inflammation (90). The study demonstrated that in rats, a 4-month period of high-fat diet (HFD) feeding leads to activation of inflammatory pathways such as NF- $\kappa B$ and JNK in the MBH with the production of pro-inflammatory cytokines TNF- $\alpha$, IL-1 $\beta$, and IL-6. These findings were later replicated and extended in rodents, humans, and non-human primates (89,91-98).

Interestingly, HFD leads to hypothalamic inflammation due to over-expression of pro-inflammatory cytokines with activation and proliferation of microglia rapidly, even within the course of $24 \mathrm{~h}$ (91), weeks before the onset of obesity and the associated metabolic disturbances $(91,99)$, suggesting that hypothalamic inflammation is a response to nutrients rather than peripheral inflammation. Importantly, the gliosis observed in the hypothalamus under HFD feeding is reversible for a short time (2-3 weeks) and it has been suggested that it serves a protective role against "injury" induced by overload of dietary fat $(49,91)$.

\section{Dietary fats can modulate microglial function}

Evidence suggest that, in respect to macronutrient content, diets high in fat, especially, saturated fats, lead to obesity and metabolic syndrome $(100,101)$, as well as hypothalamic inflammation (102). Moreover, under obese conditions, the adipose tissue releases large amounts of non-esterified saturated fatty acid in the circulation (103), which can cross the blood brain barrier (BBB) (104) and stimulate both neurons and glial cells (105). The direct and indirect effects of different lipids on microglial function have been extensively reviewed by Leyrolle et al (106).

Based on the number of double bonds, three main families of fatty acids can be distinguished, namely the saturated (SFA), monounsaturated (MUFA) or polyunsaturated (PUFA) fatty acids (106). Differences in the effects of each family on microglial function have been demonstrated.

\section{Microglia and saturated fatty acids}

Obesity-inducing diets are high in SFA, particularly palmitate
(106). After ingestion, SFA can reach the brain, where they are taken up by microglia and induce hypothalamic inflammation (93). This is supported by in vitro studies, showing increased pro-inflammatory activity of cultured microglial cells $(93,107-$ 110). Saturated fatty acids activate microglia via various toll-like receptors (TLRs) (111). In particular, after palmitic acid stimulation, the TLR4-initiated signaling pathway induces cytokine release from microglia with subsequent neuronal damage in the hypothalamus, which, in turn, disrupts the circuitry controlling homeostatic eating $(48,112)$. Microglial depletion cancels SFAinduced inflammation in hypothalamic slices, and, remarkably, enhances leptin signaling and reduces food intake (93).

\section{Microglia and monounsaturated fatty acids}

In contrast to SFA, MUFA such as oleate does not trigger the release of pro-inflammatory cytokines of cultured microglia (93). Oleate has also been shown to prevent 7-ketocholesterolinduced cytotoxicity (113). The anti-inflammatory effects of oleate can be partially explained by the higher affinity of MUFA compared to SFA for the transcription factor peroxisome proliferator-activated receptor, that is involved in anti-inflammatory processes (114).

\section{Microglia and polyunsaturated fatty acids}

The two main PUFA families are n-3 and n-6 PUFA (115). It is considered that n-3 PUFA and their derivatives are rather antiinflammatory while n-6 PUFA and their derivatives are pro-inflammatory (116). An important hallmark of the modern Western diet is a decrease of the n-3/n-6 PUFA ratio (117). This is of practical importance, since it has been shown that diet enriched with n-3 PUFA may be able to inhibit neuroinflammation (118). Linoleic acid, a n-6 PUFA has been shown to reverse the inflammatory responses induced by palmitic acid treatment in microglial cells (119). In mice, lifelong dietary n-3 PUFA deficiency leads to alterations in microglia composition (120). Several n-3 PUFA have been shown to attenuate microglial activation due to various challenges (121-130), possibly due to inhibition of the inflammatory signaling cascades NFKB, and MAPK and activation of the anti-inflammatory factors PPAR, retinoid X receptor (RXR) and the G-protein coupled receptor 120 (GPR120) (106,116,131-133). PUFA have also been shown to modulate microglial phagocytic activity against $\mathrm{A} \beta$ particles, myelin debris, synaptic elements and apoptotic neurons $(67,106,134$, 135). Deficiency of n-3 PUFAs during development has been shown to increase pro-inflammatory gene expression in the hippocampus and decrease microglial motility (130). Furthermore, n-3 PUFA inhibit LPS-stimulated cytokine production by microglia in vitro $(132,136)$. 


\section{Do dietary fats really cause brain damage?}

The interpretation that dietary fats, particularly saturated fats, are an adverse stimulus, leading to brain damage should be taken with caution (137). Why would the brain be vulnerable to injury by such an acute and common stimulus (137)? Many mammals evolved to thrive on diets high in pro-inflammatory saturated fat as early as the newborn stage due to the high-fat content of mother's milk (137). Hypothalamic microgliosis is increased by higher consumption of saturated fats but this is not the case with unsaturated or short-chain fatty acids even when calories and fat content are held constant (93). This, plus the reversibility of saturated fat-induced hypothalamic microgliosis, suggests that this is a response to the overconsumption of specific nutrients, rather than "injury" (137). Furthermore, Gao et al have shown that a high-carbohydrate HFD induced hypothalamic inflammation but this is not the case in a low-carbohydrate, high-fat diet (101). Baufeld et al have demonstrated that the pro-inflammatory reaction of microglia to HFD reverses after 8 weeks, suggesting a switch to an anti-inflammatory phenotype (138). Similar observations have been reported previously (139). Importantly, there was no excessive reaction of microglia when stimulated by plasma from HFD-fed animals (138). These differences in observations can be accounted by variations in the experimental design (138), particularly in terms of using neonatal versus adult microglia, which are considered functionally different populations (140). Furthermore, postmortem analysis of human brains revealed significant microglial alterations in the hypothalamus of obese subjects, however, no such changes were observed in the cortex (138).

The picture gets even more complicated when we take the ketogenic diet into account.

\section{The ketogenic diet is high in fat but also neuroprotective}

The ketogenic diet has been originally used in the treatment of epilepsy since the beginning of the 20th century (141). It has a very high fat content with low carbohydrate and protein levels, thus shifting the metabolism to producing ketone bodies from fatty acids stored in the adipose tissue, as an energy source. Acetoacetate (ACA) and beta-hydroxybutyrate (BHB) are the main ketone bodies and can pass the BBB (141). The ketogenic diet has been shown to exert effects beyond covering the energy needs, including the regulation of synaptic transmission, neurotransmitter concentration, and optimization of mitochondrial function (141). As such, it has been considered neuroprotective in the context of many neurological disorders (142).

Suppression of microglial activation has been associated with the neuroprotective effects of the ketogenic diet (143-145). In- deed, microglia have the ability to metabolize both ACA and BHB (146), and several mechanisms have been proposed regarding the anti-inflammatory effects of ketones on these cells. Beta-hydroxybutyrate can increase the ramification of microglia both in vitro and in vivo $(141,147)$.

Moreover, high BHB levels can decrease proinflammatory cytokine release (148). Beta-hydroxybutyrate can activate the hydroxy-carboxylic acid receptor 2 (HCA2), expressed by microglia (149) and inhibit neuroinflammation (150), possibly via inhibition of NF-kB activation (150). Beta-hydroxybutyrate activates G-protein-coupled receptors 109A (GPR109A) and inhibits histone deacetylases $(146,147,150,151)$. This attenuates the NF-kB pathway, resulting in reduced pro-inflammatory cytokine production (152).

Another possible mechanism for the beneficial effects of ketogenic diets can be the lower formation of advanced glycation end products (AGEs) due to low dietary glucose levels. AGEs are non-enzymatic modifications of proteins and lipids from reactions with sugars (146). Microglia have been shown to express receptors for AGEs (146), which stimulate pro-inflammatory signaling pathways $(153,154)$.

\section{Adipose tissue can influence microglia via adipokines}

When discussing the interplay between the adipose tissue and microglia in the regulation of metabolism and the mechanisms of obesity-related complications, it is of interest whether microglia can sense blood-borne molecules other than nutrients, especially adipose-derived signals. Indeed, such molecules exist, enabling the adipose-microglia crosstalk.

\section{Leptin}

Leptin is the prototypic adipokine, which has multiple functions including the regulation of appetite, body weight and energy homeostasis (155); and can enter the brain (156). Elevated levels of leptin reduce appetite and body weight (3). Obesity is associated with leptin resistance due to either a defect in leptin receptor's intracellular signaling or decreased leptin transport across the BBB $(155,157-159)$.

The mutant strain of mice $\left(\mathrm{ob}^{-} / \mathrm{ob}^{-}\right)$are genetically deficient in leptin, suffer from extreme obesity (155) and are often used as an experimental model for obesity research. Leptin has been shown to exert effects on microglia $(137,160)$. Mice lacking leptin or its receptor have lower microglial density in the $\mathrm{MBH}$ (99), which is reversible to wild-type levels when restoring the leptin signal (99). In both obesity and experimental leptin resistance, leptin levels are elevated also in the hippocampus, a key structure involved in cognition, which is associated with microglial activation (161). Interestingly, voluntary exercise increases 
leptin sensitivity and, in turn, decreases microglial activation and pro-inflammatory signaling in the hippocampus (161). In both obesity and experimental leptin resistance, leptin levels are elevated in the hippocampus (161). Mice lacking leptin have defective neurite growth in the hypothalamus (162), which can be possibly attributed to impaired microglial activity (82). Indeed, leptin has been shown to regulate microglial phagocytosis (163).

However, some studies have challenged the existence of a direct action of leptin on microglia (137). Possible indirect mechanisms involve neuron-glial interactions in the MBH (137) and activation of astrocytes by leptin, which, in turn, activate microglia (161).

\section{Adiponectin}

Adiponectin is the most abundant adipokine $(164,165)$, involved in a variety of physiological processes, including the regulation of energy metabolism, vascular physiology, and inflammation $(166,167)$. It is generally considered an anti-inflammatory molecule, and its low plasma levels have been linked to chronic inflammation $(168,169)$. Adiponectin can cross the BBB and reach the brain, where it can exert actions on both neurons and glia, including microglia (167) via its receptors, AdipoR1 and AdipoR2 $(166,170,171)$. Adiponectin has anti-depressant (172) and antiinflammatory (173) properties in mice. It has also been shown to be a candidate mediator of the positive effects of exercise and environmental enrichment on neurogenesis, mood, and cognition (174). Nicolas et al have shown that elevated adiponectin levels in the brain regulate microglial phenotype and activation, leading to reduction in neuroinflammation and depressive-like behavior in mice (167). These effects are possibly mediated by the AdipoR1/NF-kB signaling pathway and reduction of IL-1 $\beta$, IL-6, and TNF- $\alpha$ synthesis by globular adiponectin in particular (167). On the other hand, adiponectin deficiency enhances microglial responsiveness to pro-inflammatory challenges, thus increasing brain susceptibility to inflammation (167). Furthermore, adiponectin has been shown to be a major contributor to the antidepressant effects of enriched environment via its actions on microglia (174)

\section{Adipose-derived stem cells can influence microglia}

Adult stem cell therapy involves the transplantation of either embryonic stem cells or induced pluripotent stem cells, hoping that these can rejuvenate damaged tissue by differentiating into other viable cell types (175). However, this method is associated with high costs, methodological difficulties, and ethical challenges (176).

A proposed alternative are adult stem cells, which, despite their more limited multipotentiality and self-renewal capabili- ties, can be obtained from all tissues (175). The adipose tissue is an abundant source of such cells, termed adipose-derived stem cells (ADSC), containing over 500 times more mesenchymal stem cells than bone marrow (177). These cells have been shown to be able to differentiate into multiple other cell types $(175,178,179)$ and are able to modulate inflammation (180-182).

Huang et al have shown that ADSC can survive a long time after transplantation and are able to suppress microglial activation induced by LPS, which prevented dopaminergic neuron loss in the substantia nigra in a Parkinson's disease model. Interestingly, the anti-inflammatory modulatory effects of ADSC on microglia took a long time to manifest, which in the case of the study was around 4-6 months (178).

The importance of such studies is that they show how the adipose tissue can influence microglial function via mechanisms beyond molecular signaling.

\section{The other direction: microglia can influence adipose tissue}

The idea of adipose tissue's influence on microglia, although unintuitive, makes sense in light of the current systemic inflammatory concept of obesity. However, the adipose-microglia crosstalk becomes even more interesting if we consider the other direction: can microglia influence the adipose tissue? In light of the current evidence, we can imagine how microglia can modulate neuroinflammation in the hypothalamus and, in turn, affect feeding behavior and energy homeostasis.

The adipose tissue signals the current availability of nutrients via adipokines to the hypothalamus, which, in turn, controls energy homeostasis, feeding behavior and metabolic rate (183). Hypothalamic inflammation, particularly in the $\mathrm{MBH}$, has been shown to modulate the control of insulin resistance, as well as energy intake and expenditure $(184,185)$. Surprisingly, homeostatic feeding circuits in the hypothalamus are regulated by peptides and hormones which can also modulate neuroinflammation $(48,111)$. If microglia are either depleted or their activation is suppressed pharmacologically, mice fed a HFD show decreased food intake and gain less weight. A possible mechanism is that reducing inflammation enhances leptin signaling (93). Interestingly, the opposite has also been shown: activating microglia leads to stimulation of food intake and weight gain in mice fed a normal non-obesogenic diet (186). Microglia of mice fed a high-carbohydrate high-fat diet secrete TNF- $a$ which disrupts pro-opiomelanocortin-producing anorexigenic neurons in the $\mathrm{MBH}$ (187). Obesity is associated with dysfunction of these neurons $(188,189)$. Moreover, in rats, Cx3cr1-driven microglia and monocyte ablation leads to disruption of the gustatory circuitry at the hypothalamic paraventricular nucleus, which, in turn, re- 
sults in anorexia and weight loss (190).

Central application of an antimitotic agent inhibits microglial expansion in the hypothalamic arcuate nucleus, restores leptin sensitivity and limits food intake and consequent weight gain (191). Disruption of hypothalamic microglia via subcutaneous application of liraglutide or canagliflozin in obese insulin-resistant mice improves insulin resistance, glucose homeostasis, and decreases fat and triglyceride content $(192,193)$.

\section{Transgenerational microglial adipobiology}

There is accumulating evidence that maternal obesity can affect the long-term health of the offspring (194-197). Maternal nutrition as well can influence the energy homeostasis of offspring even into adulthood $(198,199)$. Can microglial activation explain this "metabolic programming"?

Exposure to HFD in both rodents and non-human primates activates the maternal immune system, leading to increased brain inflammatory markers in the offspring $(96,200-202)$. Furthermore, the offspring of mice fed a HFD during both pregnancy and lactation have increased microglial activation (200, 203), despite the lack of any challenges in their diet. Maternal programming by exposure to a cafeteria diet induced a plasma lipotoxic profile in the offspring. This lead to microglial activation and disrupted ghrelin sensitivity which was associated with overfeeding behavior after fasting (204).

Interestingly, n-3 PUFA supplementation from the onset of pregnancy until weaning has been shown to modify the fatty acid content and phospholipid class distribution in the offspring's microglia (120).

\section{Summary and future directions}

This article introduces the concept of "microglial adipobiology" as a framework, explaining how the bidirectional adipose-tomicroglia crosstalk can account for the neuropsychiatric complications seen in obesity, as well as, how microglial function can affect food intake, energy homeostasis, and, ultimately, adipose tissue function (Fig. 1). Several mechanistic links have been reviewed. First, obesity leads to inflammation of the adipose tissue, which releases pro-inflammatory cytokines, which cross the $\mathrm{BBB}$, activate microglia and induce neuroinflammation. Second, dietary fatty acids have been shown to affect microglial function in both positive and negative ways, depending on the fat's quantity and type. Third, due to obesity, the adipose tissue alters its secretory profile of several important adipokines, including leptin, adiponectin, NGF and BDNF, which too can enter the brain and change microglial function. Fourth, under experimental conditions, adipose-derived stem cells can affect microglia, not only showing a possible adipose-to-microglia mechanism for

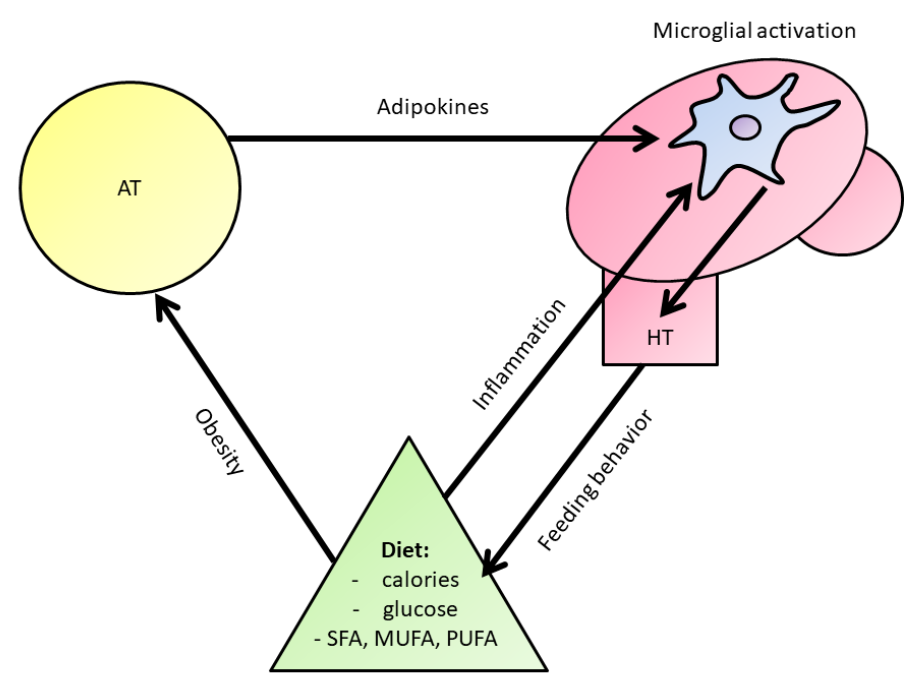

Figure 1. Schematic presentation of a summary of microglial adipobiology. Diet can modulate microglial activation either directly via the specific effects of certain dietary components, or indirectly via inducing obesity and the associated adipose tissue inflammation, which favors a pro-inflammatory adipokine secretory profile, causing neuroinflammation. Microglia, in turn, can influence the central control over energy homeostasis in the hypothalamus, thus affecting feeding behavior and, ultimately, adipose tissue function. AT, adipose tissue; $\mathrm{HT}$, hypothalamus; SFA, saturated fatty acids; MUFA, monounsaturated fatty acids; PUFA, polyunsaturated fatty acids.

communication but also opening a new possibility for stem cellbased neurotherapies. Fifth, microglia can affect obesity and adipose tissue function via modulating the hypothalamic control over feeding behavior and energy metabolism. Finally, the concept of "transgenerational microglial adipobiology" is proposed as a way of explaining how maternal obesity and high-fat feeding can activate the offspring's microglia and, in turn, their neurodevelopment, behavior, and metabolism.

The proposed framework reveals several possibilities for therapeutic applications. First, the pro-inflammatory adipose-tomicroglia signaling, including specific adipokines such as leptin, adiponectin, NGF and BDNF is a potential target for pharmacological interventions, aimed at reducing neuropsychiatric complications in obesity. Second, understanding how the different types of dietary fatty acids specifically affect microglia can lead to relatively easy ways to control neuroinflammation via targeted nutritional interventions. Third, considering the other direction, namely the microglia-to-adipose signaling, we can propose a new method for the management of obesity via targeting microglia in the $\mathrm{MBH}$, thus, affecting the central control of energy 
homeostasis. Finally, all future interventions can be used to prevent the adverse cognitive and metabolic outcomes seen in the offspring of obese mothers.

As evidence for the associations between obesity, adipose tissue and the brain continues to accumulate, our knowledge expands rapidly and we risk losing the forest for the trees, thus, we need a theoretical framework that can help organize the "big data" in the field. The concept of microglial adipobiology is such a perspective aiming to clarify at least one line of reasoning, and may, hopefully, provide a basis for future hypotheses.

\section{Conflict of interest}

None

\section{References}

1. Abdelaal M, le Roux CW, Docherty NG. Morbidity and mortality associated with obesity. Ann Transl Med 2017; 5(7):161-161. DOI:10.21037/atm.2017.03.107

2. O'Brien PD, Hinder LM, Callaghan BC, Feldman EL. Neurological consequences of obesity. Lancet Neurol 2017; 16(6):465-477. DOI:10.1016/S1474-4422(17)30084-4

3. Lake J. Urgent need for improved mental health care and a more collaborative model of care. Perm J 2017. 21:17-024. DOI:10.7812/TPP/17-024

4. Chaldakov G, Stankulov I, Hristova M, Ghenev P. Adipobiology of disease: Adipokines and adipokine-targeted pharmacology. Curr Pharm Des 2003; 9(12):1023-1031. DOI:10.2174/1381612033455152

5. Rančić G, Fiore M, Pancheva R, Tunçel N, Beltowski J, Zhelezov M, Ghenev P, Hinev A, et al. Adipose tissue: The renaissance marked by four paradigm shifts. Adipobiology 2014; 6: 49-53. DOI:10.14748/adipo.v6.1136

6. Chaldakov GN, Fiore M, Tonchev AB, Hristova MG, Rancic G, Aloe L. The adipose tissue as a third brain. Obes $\mathrm{Me}$ tab 2009; 5(3-4):94-96.

7. Aloe L, Tonchev AB, Maucher A, Fiore M, Zhelezov MD, Chaldakov GN. Adipobiology of the brain: From brain diabetes to adipose Alzheimer's disease. Adipobiology 2015; 7:37. DOI:10.14748/adipo.v7.1559

8. Radtke FA, Chapman G, Hall J, Syed YA. Modulating Neuroinflammation to Treat Neuropsychiatric Disorders. BioMed Res Int 2017; 2017:1-21. DOI:10.1155/2017/5071786

9. Salter MW, Stevens B. Microglia emerge as central players in brain disease. Nat Med 2017; 23(9):1018-1027. DOI:10.1038/nm.4397

10. Yanev S, Aloe L, Fiore M, Chaldakov GN. Neurotrophic and metabotrophic potential of nerve growth factor and brain-derived neurotrophic factor: Linking cardiometabol- ic and neuropsychiatric diseases. World J Pharmacol 2013; 2(4):92. DOI:10.5497/wjp.v2.i4.92

11. Ogden CL, Flegal KM. Prevalence of Obesity in the United States, 2009-2010. NCHS Data Brief 2012; 82:1-8. DOI:10.1001/jama.2014.6228

12. World Health Organization. Obesity and overweight. 2017. http://www.who.int/news-room/fact-sheets/detail/obesityand-overweight.

13. Kelly T, Yang W, Chen C-S, Reynolds K, He J. Global burden of obesity in 2005 and projections to 2030. Int J Obes 2008; 32(9):1431-1437. DOI:10.1038/ijo.2008.102

14. Hauner, H. (2017). Obesity and diabetes. In Textbook of Diabetes, eds R. I. G., 2017; 215-228

15. Jiang S-Z, Lu W, Zong X-F, Ruan H-Y, Liu Y. Obesity and hypertension. Exp Ther Med 2016; 12(4):2395-2399. DOI:10.3892/etm.2016.3667

16. Malnick SDH. The medical complications of obesity. QJM 2006; 99(9):565-579. DOI:10.1093/qjmed/hcl085

17. Cournot M, Marquie JC, Ansiau D, et al. Relation between body mass index and cognitive function in healthy middleaged men and women. Neurology 2006; 67(7):1208-1214. DOI:10.1212/01.wnl.0000238082.13860.50

18. Gunstad J, Paul RH, Cohen RA, Tate DF, Spitznagel $\mathrm{MB}$, Gordon E. Elevated body mass index is associated with executive dysfunction in otherwise healthy adults. Compr Psychiatry 2007; 48(1):57-61. DOI:10.1016/j. comppsych.2006.05.001

19. Li Y, Dai Q, Jackson JC, Zhang J. Overweight Is Associated With Decreased Cognitive Functioning Among School-age Children and Adolescents. Obesity 2008; 16(8):1809-1815. DOI:10.1038/oby.2008.296

20. Smith E, Hay P, Campbell L, Trollor JN. A review of the association between obesity and cognitive function across the lifespan: implications for novel approaches to prevention and treatment: Obesity and cognitive function across lifespan. Obes Rev 2011; 12(9):740-755. DOI:10.1111/j.1467789X.2011.00920.x

21. Yang Y, Shields GS, Guo C, Liu Y. Executive function performance in obesity and overweight individuals: A metaanalysis and review. Neurosci Biobehav Rev 2018; 84:225244. DOI:10.1016/j.neubiorev.2017.11.020

22. Favieri F, Forte G, Casagrande M. The Executive Functions in Overweight and Obesity: A Systematic Review of Neuropsychological Cross-Sectional and Longitudinal Studies. Front Psychol 2019; 10. DOI:10.3389/fpsyg.2019.02126

23. Ward MA, Carlsson CM, Trivedi MA, Sager MA, Johnson SC. The effect of body mass index on global brain volume in middle-aged adults: a cross sectional study. BMC Neurol 
2005; 5(1). DOI:10.1186/1471-2377-5-23

24. Raji CA, Ho AJ, Parikshak NN, et al. Brain structure and obesity. Hum Brain Mapp 2009; 31(3):353-64. DOI:10.1002/ hbm. 20870

25. Sanderlin AH, Todem D, Bozoki AC. Corrigendum: Obesity and Co-morbid Conditions Are Associated with Specific Neuropsychiatric Symptoms in Mild Cognitive Impairment. Front Aging Neurosci 2017; 9:325. DOI:10.3389/ fnagi.2017.00325

26. Beydoun MA, Beydoun HA, Wang Y. Obesity and central obesity as risk factors for incident dementia and its subtypes: a systematic review and meta-analysis. Obes Rev 2008; 9(3):204-218. DOI:10.1111/j.1467-789X.2008.00473.x

27. Profenno LA, Porsteinsson AP, Faraone SV. Meta-Analysis of Alzheimer's Disease Risk with Obesity, Diabetes, and Related Disorders. Biol Psychiatry 2010; 67(6):505-512. DOI:10.1016/j.biopsych.2009.02.013

28. Hagnell O. Chapter 6: Repeated incidence and prevalence studies of mental disorders in a total population followed during 25 years. The Lundby Study, Sweden. Acta Psychiatr Scand 1989; 79(S348):61-77. DOI:10.1111/j.1600-0447.1989.tb05216.x

29. Hidaka BH. Depression as a disease of modernity: Explanations for increasing prevalence. J Affect Disord 2012; 140(3):205-214. DOI:10.1016/j.jad.2011.12.036

30. Steel Z, Marnane C, Iranpour C, et al. The global prevalence of common mental disorders: a systematic review and meta-analysis 1980-2013. Int J Epidemiol 2014; 43(2):476-493. DOI:10.1093/ije/dyu038

31. Carpiniello B, Pinna F, Pillai G, et al. Obesity and psychopathology. A study of psychiatric comorbidity among patients attending a specialist obesity unit. Epidemiol Psichiatr Soc 2009; 18(2):119-127. DOI:10.1017/S1121189X00001007

32. de Wit L, Luppino F, van Straten A, Penninx B, Zitman F, Cuijpers P. Depression and obesity: A meta-analysis of community-based studies. Psychiatry Res 2010; 178(2):230235. DOI:10.1016/j.psychres.2009.04.015

33. Gariepy G, Nitka D, Schmitz N. The association between obesity and anxiety disorders in the population: a systematic review and meta-analysis. Int J Obes 2010; 34(3):407419. DOI:10.1038/ijo.2009.252

34. Luppino FS, de Wit LM, Bouvy PF, et al. Overweight, Obesity, and Depression: A Systematic Review and Metaanalysis of Longitudinal Studies. Arch Gen Psychiatry 2010; 67(3):220. DOI:10.1001/archgenpsychiatry.2010.2

35. Carey M, Small H, Yoong SL, Boyes A, Bisquera A, SansonFisher R. Prevalence of comorbid depression and obesity in general practice: a cross-sectional survey. Br J Gen Pract
2014; 64(620):e122-e127. DOI:10.3399/bjgp14X677482

36. Jacka FN, Pasco JA, Mykletun A, et al. Association of Western and Traditional Diets With Depression and Anxiety in Women. Am J Psychiatry 2010; 167(3):305-11. DOI: 10.1176/appi.ajp.2009.09060881.

37. O’Neil A, Quirk SE, Housden S, et al. Relationship Between Diet and Mental Health in Children and Adolescents: A Systematic Review. Am J Public Health 2014; 104(10):e31e42. DOI:10.2105/AJPH.2014.302110

38. Logan AC, Jacka FN. Nutritional psychiatry research: an emerging discipline and its intersection with global urbanization, environmental challenges and the evolutionary mismatch. J Physiol Anthropol 2014; 33(1). DOI:10.1186/18806805-33-22

39. Renes J, Mariman E. Application of proteomics technology in adipocyte biology. Mol Biosyst 2013; 9(6):1076. DOI:10.1039/c3mb25596d

40. Trayhurn P, Bing C, Wood IS. Adipose Tissue and Adipokines-Energy Regulation from the Human Perspective. J Nutr 2006; 136(7):1935S-1939S. DOI:10.1093/ jn/136.7.1935S

41. Coope A, Milanski M, Araújo EP, et al. AdipoR1 mediates the anorexigenic and insulin/leptin-like actions of adiponectin in the hypothalamus. FEBS Lett 2008; 582(10):1471-1476. DOI:10.1016/j.febslet.2008.03.037

42. Chaldakov GN. Triactome: neuro-immune-adipose interactions. Implication in vascular biology. Front Immunol 2014; 5:130. DOI: 10.3389/fimmu.2014.00130

43. Chaldakov GN, Fiore M, Stankulov IS, et al. Neurotrophin presence in human coronary atherosclerosis and metabolic syndrome: a role for NGF and BDNF in cardiovascular disease? Prog Brain Res 2004; 146:279-289. DOI:10.1016/ S0079-6123(03)46018-4

44. Schmidt FM, Weschenfelder J, Sander C, et al. Inflammatory Cytokines in General and Central Obesity and Modulating Effects of Physical Activity. PloS One 2015; 10(3):e0121971. DOI:10.1371/journal.pone.0121971

45. Saltiel AR, Olefsky JM. Inflammatory mechanisms linking obesity and metabolic disease. J Clin Invest 2017; 127(1):14. DOI:10.1172/JCI92035

46. Cope EC, LaMarca EA, Monari PK, et al. Microglia Play an Active Role in Obesity-Associated Cognitive Decline. $J$ Neurosci 2018; 38(41):8889-8904. DOI:10.1523/JNEUROSCI.0789-18.2018

47. Gregor MF, Hotamisligil GS. Inflammatory Mechanisms in Obesity. Annu Rev Immunol 2011; 29(1):415-445. DOI:10.1146/annurev-immunol-031210-101322

48. Butler MJ, Eckel LA. Eating as a motivated behavior: mod- 
ulatory effect of high fat diets on energy homeostasis, reward processing and neuroinflammation. Integr Zool 2018; 13(6):673-686. DOI:10.1111/1749-4877.12340

49. Le Thuc O, Stobbe K, Cansell C, Nahon J-L, Blondeau N, Rovère C. Hypothalamic Inflammation and Energy Balance Disruptions: Spotlight on Chemokines. Front Endocrinol 2017; 8:197. DOI:10.3389/fendo.2017.00197

50. Skaper SD, Facci L, Zusso M, Giusti P. An InflammationCentric View of Neurological Disease: Beyond the Neuron. Front Cell Neurosci 2018; 12:72. DOI:10.3389/fncel.2018.00072

51. Lurie DI. An Integrative Approach to Neuroinflammation in Psychiatric disorders and Neuropathic Pain. J Exp Neurosci 2018;12:117906951879363. DOI:10.1177/1179069518793639

52. González H, Elgueta D, Montoya A, Pacheco R. Neuroimmune regulation of microglial activity involved in neuroinflammation and neurodegenerative diseases. $J$ Neuroimmunol 2014; 274(1-2):1-13. DOI:10.1016/j.jneuroim.2014.07.012

53. Martín A, Domercq M, Matute C. Inflammation in stroke: the role of cholinergic, purinergic and glutamatergic signaling. Ther Adv Neurol Disord 2018; 11:175628641877426. DOI:10.1177/1756286418774267

54. Dantzer R, O’Connor JC, Freund GG, Johnson RW, Kelley KW. From inflammation to sickness and depression: when the immune system subjugates the brain. Nat Rev Neurosci 2008; 9(1):46-56. DOI:10.1038/nrn2297

55. Aguzzi A, Barres BA, Bennett ML. Microglia: scapegoat, saboteur, or something else? Science 2013; 339(6116):156161. DOI: 10.1126/science. 1227901

56. Ginhoux F, Greter M, Leboeuf M, et al. Fate mapping analysis reveals that adult microglia derive from primitive macrophages. Science 2010; 330(6005):841-845. DOI: 10.1126/ science. 1194637

57. Hoeffel G, Ginhoux F. Ontogeny of Tissue-Resident Macrophages. Front Immunol 2015; 6:486. DOI:10.3389/fimmu.2015.00486

58. Ginhoux F, Guilliams M. Tissue-Resident Macrophage Ontogeny and Homeostasis. Immunity 2016; 44(3):439-449. DOI:10.1016/j.immuni.2016.02.024

59. Kierdorf K, Erny D, Goldmann T, et al. Microglia emerge from erythromyeloid precursors via $\mathrm{Pu}$. 1-and Irf8-dependent pathways. Nat Neurosci 2013; 16(3):273-280. DOI: 10.1038/nn.3318

60. Gomez Perdiguero E, Klapproth K, Schulz C, et al. Tissueresident macrophages originate from yolk-sac-derived erythro-myeloid progenitors. Nature 2015; 518(7540):547-
551. DOI:10.1038/nature13989

61. Nimmerjahn A. Resting Microglial Cells Are Highly Dynamic Surveillants of Brain Parenchyma in Vivo. Science 2005; 308(5726):1314-1318. DOI:10.1126/science.1110647

62. Schafer DP, Lehrman EK, Kautzman AG, et al. Microglia Sculpt Postnatal Neural Circuits in an Activity and Complement-Dependent Manner. Neuron 2012; 74(4):691-705. DOI:10.1016/j.neuron.2012.03.026

63. Paolicelli RC, Bolasco G, Pagani F, et al. Synaptic Pruning by Microglia Is Necessary for Normal Brain Development. Science 2011; 333(6048):1456-1458. DOI:10.1126/ science. 1202529

64. Tremblay M-E, Stevens B, Sierra A, Wake H, Bessis A, Nimmerjahn A. The Role of Microglia in the Healthy Brain. $J$ Neurosci 2011; 31(45):16064-16069. DOI:10.1523/JNEUROSCI.4158-11.2011

65. Wake H, Moorhouse AJ, Miyamoto A, Nabekura J. Microglia: actively surveying and shaping neuronal circuit structure and function. Trends Neurosci 2013; 36(4):209-217. DOI:10.1016/j.tins.2012.11.007

66. Li Y, Du X, Liu C, Wen Z, Du J. Reciprocal Regulation between Resting Microglial Dynamics and Neuronal Activity In Vivo. Dev Cell 2012; 23(6):1189-1202. DOI:10.1016/j. devcel.2012.10.027

67. Abiega O, Beccari S, Diaz-Aparicio I, et al. Neuronal Hyperactivity Disturbs ATP Microgradients, Impairs Microglial Motility, and Reduces Phagocytic Receptor Expression Triggering Apoptosis/Microglial Phagocytosis Uncoupling. PLOS Biol 2016;14(5):e1002466. DOI:10.1371/journal. pbio. 1002466

68. Tremblay M-È, Lowery RL, Majewska AK. Microglial Interactions with Synapses Are Modulated by Visual Experience. PLoS Biol 2010; 8(11):e1000527. DOI:10.1371/journal.pbio.1000527

69. Parkhurst CN, Yang G, Ninan I, et al. Microglia Promote Learning-Dependent Synapse Formation through BrainDerived Neurotrophic Factor. Cell 2013; 155(7):1596-1609. DOI:10.1016/j.cell.2013.11.030

70. Kettenmann H, Hanisch U-K, Noda M, Verkhratsky A. Physiology of Microglia. Physiol Rev 2011; 91(2):461-553. DOI:10.1152/physrev.00011.2010

71. Heneka MT, Kummer MP, Latz E. Innate immune activation in neurodegenerative disease. Nat Rev Immunol 2014; 14(7):463-477. DOI:10.1038/nri3705

72. Heppner FL, Ransohoff RM, Becher B. Immune attack: the role of inflammation in Alzheimer disease. Nat Rev Neurosci 2015; 16(6):358-372. DOI:10.1038/nrn3880

73. Penzes P, Cahill ME, Jones KA, VanLeeuwen J-E, Woolfrey 
KM. Dendritic spine pathology in neuropsychiatric disorders. Nat Neurosci 2011; 14(3):285-293. DOI:10.1038/ nn. 2741

74. Li Q, Barres BA. Microglia and macrophages in brain homeostasis and disease. Nat Rev Immunol 2017; 18(4):225242. DOI:10.1038/nri.2017.125

75. Colonna M, Butovsky O. Microglia Function in the Central Nervous System During Health and Neurodegeneration. Annu Rev Immunol 2017; 35(1):441-468. DOI:10.1146/ annurev-immunol-051116-052358

76. Karperien A, Ahammer H, Jelinek HF. Quantitating the subtleties of microglial morphology with fractal analysis. Front Cell Neurosci 2013; 30;7:3. DOI:10.3389/fncel.2013.00003

77. McWhorter FY, Wang T, Nguyen P, Chung T, Liu WF. Modulation of macrophage phenotype by cell shape. Proc Natl Acad Sci 2013; 110(43):17253-17258. DOI:10.1073/ pnas. 1308887110

78. Ren Y, Zhou X, He X. Function of microglia and macrophages in secondary damage after spinal cord injury. Neural Regen Res 2014; 9(20):1787. DOI:10.4103/16735374.143423

79. Zhou Y, Danbolt NC. Glutamate as a neurotransmitter in the healthy brain. J Neural Transm 2014; 121(8):799-817. DOI:10.1007/s00702-014-1180-8

80. Benakis C, Garcia-Bonilla L, Iadecola C, Anrather J. The role of microglia and myeloid immune cells in acute cerebral ischemia. Front Cell Neurosci 2015; 14;8:461. DOI:10.3389/ fncel.2014.00461

81. Hoogland ICM, Houbolt C, van Westerloo DJ, van Gool WA, van de Beek D. Systemic inflammation and microglial activation: systematic review of animal experiments. J Neuroinflammation 2015; 12:114. DOI:10.1186/s12974-0150332-6

82. Kälin S, Heppner FL, Bechmann I, Prinz M, Tschöp MH, Yi C-X. Hypothalamic innate immune reaction in obesity. Nat Rev Endocrinol 2015; 11(6):339-351. DOI:10.1038/ nrendo.2015.48

83. Vitkovic L, Konsman JP, Bockaert J, Dantzer R, Homburger V, Jacque C. Cytokine signals propagate through the brain. Mol Psychiatry 2000; 5(6):604-615. DOI:10.1038/ sj.mp. 4000813

84. Varatharaj A, Galea I. The blood-brain barrier in systemic inflammation. Brain Behav Immun 2017; 60:1-12. DOI:10.1016/j.bbi.2016.03.010

85. McCusker RH, Kelley KW. Immune-neural connections: how the immune system's response to infectious agents influences behavior. J Exp Biol 2013; 216(1):84-98.
DOI:10.1242/jeb.073411

86. Bocarsly ME, Fasolino M, Kane GA, et al. Obesity diminishes synaptic markers, alters microglial morphology, and impairs cognitive function. Proc Natl Acad Sci 2015; 112(51):15731-15736. DOI:10.1073/pnas.1511593112

87. Hao S, Dey A, Yu X, Stranahan AM. Dietary obesity reversibly induces synaptic stripping by microglia and impairs hippocampal plasticity. Brain Behav Immun 2016; 51:230239. DOI:10.1016/j.bbi.2015.08.023

88. Yi C-X, Tschop MH, Woods SC, Hofmann SM. Highfat-diet exposure induces IgG accumulation in hypothalamic microglia. Dis Model Mech 2012; 5(5):686-690. DOI:10.1242/dmm.009464

89. Valdearcos M, Xu AW, Koliwad SK. Hypothalamic Inflammation in the Control of Metabolic Function. Annu Rev Physiol 2015; 77(1):131-160. DOI:10.1146/annurev-physiol-021014-071656

90. De Souza CT, Araujo EP, Bordin S, et al. Consumption of a Fat-Rich Diet Activates a Proinflammatory Response and Induces Insulin Resistance in the Hypothalamus. Endocrinology 2005; 146(10):4192-4199. DOI:10.1210/en.20041520

91. Thaler JP, Yi C-X, Schur EA, et al. Obesity is associated with hypothalamic injury in rodents and humans. J Clin Invest 2012; 122(1):153-162. DOI:10.1172/JCI59660

92. Kleinridders A, Schenten D, Könner AC, et al. MyD88 Signaling in the CNS Is Required for Development of Fatty Acid-Induced Leptin Resistance and Diet-Induced Obesity. Cell Metab 2009; 10(4):249-259. DOI:10.1016/j. cmet.2009.08.013

93. Valdearcos M, Robblee MM, Benjamin DI, Nomura DK, Xu AW, Koliwad SK. Microglia Dictate the Impact of Saturated Fat Consumption on Hypothalamic Inflammation and Neuronal Function. Cell Rep 2014; 9(6):2124-2138. DOI:10.1016/j.celrep.2014.11.018

94. Zhang X, Zhang G, Zhang H, Karin M, Bai H, Cai D. Hypothalamic IKK $\beta / \mathrm{NF}-\mathrm{kB}$ and ER Stress Link Overnutrition to Energy Imbalance and Obesity. Cell 2008; 135(1):61-73. DOI:10.1016/j.cell.2008.07.043

95. Posey KA, Clegg DJ, Printz RL, et al. Hypothalamic proinflammatory lipid accumulation, inflammation, and insulin resistance in rats fed a high-fat diet. Am J Physiol-Endocrinol Metab 2009; 296(5):E1003-E1012. DOI:10.1152/ ajpendo.90377.2008

96. Grayson BE, Levasseur PR, Williams SM, Smith MS, Marks DL, Grove KL. Changes in Melanocortin Expression and Inflammatory Pathways in Fetal Offspring of Nonhuman Primates Fed a High-Fat Diet. Endocrinology 2010; 
151(4):1622-1632. DOI:10.1210/en.2009-1019

97. Holland WL, Bikman BT, Wang L-P, et al. Lipid-induced insulin resistance mediated by the proinflammatory receptor TLR4 requires saturated fatty acid-induced ceramide biosynthesis in mice. J Clin Invest 2011; 121(5):1858-1870. DOI:10.1172/JCI43378

98. Maric T, Woodside B, Luheshi GN. The effects of dietary saturated fat on basal hypothalamic neuroinflammation in rats. Brain Behav Immun 2014; 36:35-45. DOI:10.1016/j. bbi.2013.09.011

99. Gao Y, Ottaway N, Schriever SC, et al. Hormones and diet, but not body weight, control hypothalamic microglial activity: Hypothalamic microglia in obesity. Glia 2014; 62(1):17-25. DOI:10.1002/glia.22580

100. Vessby B. Dietary fat, fatty acid composition in plasma and the metabolic syndrome. Curr Opin Lipidol 2003; 14(1):1519. DOI:10.1097/00041433-200302000-00004

101. Gao Y, Bielohuby M, Fleming T, et al. Dietary sugars, not lipids, drive hypothalamic inflammation. Mol Metab 2017; 6(8):897-908. DOI:10.1016/j.molmet.2017.06.008

102. Milanski M, Degasperi G, Coope A, et al. Saturated Fatty Acids Produce an Inflammatory Response Predominantly through the Activation of TLR4 Signaling in Hypothalamus: Implications for the Pathogenesis of Obesity. $J$ Neurosci 2009; 29(2):359-370. DOI:10.1523/JNEUROSCI.2760-08.2009

103. Yang J, Kim C-S, Tu T, et al. Quercetin Protects ObesityInduced Hypothalamic Inflammation by Reducing Microglia-Mediated Inflammatory Responses via HO-1 Induction. Nutrients 2017; 9(7):650. DOI:10.3390/nu9070650

104. Spector R. Fatty Acid Transport Through the Blood-Brain Barrier. J Neurochem 1988;50(2):639-643. DOI:10.1111/ j.1471-4159.1988.tb02958.x

105. Argente-ArizÃ3n P, Freire-Regatillo A, Argente J, Chowen JA. Role of Non-Neuronal Cells in Body Weight and Appetite Control. Front Endocrinol 2015;6:42. DOI:10.3389/ fendo.2015.00042

106. Leyrolle Q, Layé S, Nadjar A. Direct and indirect effects of lipids on microglia function. Neurosci Lett 2019; 708:134348. DOI:10.1016/j.neulet.2019.134348

107. Button EB, Mitchell AS, Domingos MM, et al. Microglial Cell Activation Increases Saturated and Decreases Monounsaturated Fatty Acid Content, but Both Lipid Species are Proinflammatory. Lipids 2014; 49(4):305-316. DOI:10.1007/s11745-014-3882-y

108. Tracy LM, Bergqvist F, Ivanova EV, Jacobsen KT, Iverfeldt K. Exposure to the Saturated Free Fatty Acid Palmitate Alters BV-2 Microglia Inflammatory Response. J Mol Neuro- sci 2013; 51(3):805-812. DOI:10.1007/s12031-013-0068-7

109. Wang Z, Liu D, Wang F, et al. Saturated fatty acids activate microglia via Toll-like receptor 4/NF- $\kappa B$ signalling. Br J Nutr 2012; 107(2):229-241. DOI:10.1017/S0007114511002868

110. Yanguas-Casás N, Crespo-Castrillo A, de Ceballos ML, et al. Sex differences in the phagocytic and migratory activity of microglia and their impairment by palmitic acid. Glia 2018; 66(3):522-537. DOI:10.1002/glia.23263

111. Maldonado-Ruiz R, Montalvo-Martínez L, Fuentes-Mera L, Camacho A. Microglia activation due to obesity programs metabolic failure leading to type two diabetes. Nutr Diabetes 2017; 7(3):e254-e254. DOI:10.1038/nutd.2017.10

112. Delint-Ramirez I, Maldonado Ruiz R, Torre-Villalvazo I, et al. Genetic obesity alters recruitment of TANK-binding kinase 1 and AKT into hypothalamic lipid rafts domains. Neurochem Int 2015; 80:23-32. DOI:10.1016/j.neuint.2014.11.002

113. Debbabi M, Zarrouk A, Bezine M, et al. Comparison of the effects of major fatty acids present in the Mediterranean diet (oleic acid, docosahexaenoic acid) and in hydrogenated oils (elaidic acid) on 7-ketocholesterol-induced oxiapoptophagy in microglial BV-2 cells. Chem Phys Lipids 2017; 207:151-170. DOI:10.1016/j.chemphyslip.2017.04.002

114. Hostetler HA, Petrescu AD, Kier AB, Schroeder F. Peroxisome Proliferator-activated Receptor a Interacts with High Affinity and Is Conformationally Responsive to Endogenous Ligands. J Biol Chem 2005; 280(19):18667-18682. DOI:10.1074/jbc.M412062200

115. Bazinet RP, Layé S. Polyunsaturated fatty acids and their metabolites in brain function and disease. Nat Rev Neurosci 2014; 15(12):771-785. DOI:10.1038/nrn3820

116. Layé S, Nadjar A, Joffre C, Bazinet RP. Anti-Inflammatory Effects of Omega-3 Fatty Acids in the Brain: Physiological Mechanisms and Relevance to Pharmacology. Pharmacol Rev 2018; 70(1):12-38. DOI:10.1124/pr.117.014092

117. Stark KD, Van Elswyk ME, Higgins MR, Weatherford CA, Salem N. Global survey of the omega-3 fatty acids, docosahexaenoic acid and eicosapentaenoic acid in the blood stream of healthy adults. Prog Lipid Res 2016; 63:132-152. DOI:10.1016/j.plipres.2016.05.001

118. Orr SK, Trépanier M-O, Bazinet RP. n-3 Polyunsaturated fatty acids in animal models with neuroinflammation. Prostaglandins Leukot Essent Fatty Acids 2013; 88(1):97103. DOI:10.1016/j.plefa.2012.05.008

119. Tu TH, Kim H, Yang S, Kim JK, Kim JG. Linoleic acid rescues microglia inflammation triggered by saturated fatty acid. Biochem Biophys Res Commun 2019; 513(1):201-206. DOI:10.1016/j.bbrc.2019.03.047 
120. Rey C, Nadjar A, Joffre F, et al. Maternal n-3 polyunsaturated fatty acid dietary supply modulates microglia lipid content in the offspring. Prostaglandins Leukot Essent Fatty Acids 2018; 133:1-7. DOI:10.1016/j.plefa.2018.04.003

121. Cintra DE, Ropelle ER, Moraes JC, et al. Unsaturated Fatty Acids Revert Diet-Induced Hypothalamic Inflammation in Obesity. PLoS ONE 2012; 7(1):e30571. DOI:10.1371/journal.pone.0030571

122. Delpech J-C, Thomazeau A, Madore C, et al. Dietary n-3 PUFAs Deficiency Increases Vulnerability to Inflammation-Induced Spatial Memory Impairment. Neuropsychopharmacology 2015; 40(12):2774-2787. DOI:10.1038/ npp.2015.127

123. Delpech J-C, Madore C, Joffre C, et al. Transgenic Increase in n-3/n-6 Fatty Acid Ratio Protects Against Cognitive Deficits Induced by an Immune Challenge through Decrease of Neuroinflammation. Neuropsychopharmacology 2015; 40(3):525-536. DOI:10.1038/npp.2014.196

124. Fourrier C, Remus-Borel J, Greenhalgh AD, et al. Docosahexaenoic acid-containing choline phospholipid modulates LPS-induced neuroinflammation in vivo and in microglia in vitro. J Neuroinflammation 2017; 14(1):170. DOI:10.1186/s12974-017-0939-x

125. Hopperton KE, Trépanier M-O, Giuliano V, Bazinet RP. Brain omega-3 polyunsaturated fatty acids modulate microglia cell number and morphology in response to intracerebroventricular amyloid- $\beta$ 1-40 in mice. J Neuroinflammation 2016; 13(1):257. DOI:10.1186/s12974-016-0721-5

126. Labrousse VF, Leyrolle Q, Amadieu C, et al. Dietary omega-3 deficiency exacerbates inflammation and reveals spatial memory deficits in mice exposed to lipopolysaccharide during gestation. Brain Behav Immun 2018; 73:427-440. DOI:10.1016/j.bbi.2018.06.004

127. Labrousse VF, Nadjar A, Joffre C, et al. Short-term long chain omega3 diet protects from neuroinflammatory processes and memory impairment in aged mice. PLoS ONE 2012; 7(5):e36861. DOI:10.1371/journal.pone.0036861

128. Moranis A, Delpech J-C, De Smedt-Peyrusse V, et al. Long term adequate n-3 polyunsaturated fatty acid diet protects from depressive-like behavior but not from working memory disruption and brain cytokine expression in aged mice. Brain Behav Immun 2012; 26(5):721-731. DOI:10.1016/j. bbi.2011.11.001

129. Orr SK, Palumbo S, Bosetti F, et al. Unesterified docosahexaenoic acid is protective in neuroinflammation. J Neurochem 2013; 127(3):378-393. DOI:10.1111/jnc.12392

130. Madore C, Nadjar A, Delpech J-C, et al. Nutritional n-3 PUFAs deficiency during perinatal periods alters brain innate immune system and neuronal plasticity-associated genes. Brain Behav Immun 2014; 41:22-31. DOI:10.1016/j. bbi.2014.03.021

131. Antonietta Ajmone-Cat M, Lavinia Salvatori M, De Simone $\mathrm{R}$, et al. Docosahexaenoic acid modulates inflammatory and antineurogenic functions of activated microglial cells. $J$ Neurosci Res 2012; 90(3):575-587. doi:10.1002/jnr.22783

132. De Smedt-Peyrusse V, Sargueil F, Moranis A, Harizi H, Mongrand S, Layé S. Docosahexaenoic acid prevents lipopolysaccharide-induced cytokine production in microglial cells by inhibiting lipopolysaccharide receptor presentation but not its membrane subdomain localization. $J$ Neurochem 2008; 105(2):296-307. DOI:10.1111/j.14714159.2007.05129.x

133. Inoue $T$, Tanaka M, Masuda S, et al. Omega-3 polyunsaturated fatty acids suppress the inflammatory responses of lipopolysaccharide-stimulated mouse microglia by activating SIRT1 pathways. Biochim Biophys Acta BBA - Mol Cell Biol Lipids 2017; 1862(5):552-560. DOI:10.1016/j.bbalip.2017.02.010

134. Chen S, Zhang $\mathrm{H}, \mathrm{Pu} \mathrm{H}$, et al. n-3 PUFA supplementation benefits microglial responses to myelin pathology. Sci Rep 2015; 4:7458. DOI:10.1038/srep07458

135. Hjorth E, Zhu M, Toro VC, et al. Omega-3 fatty acids enhance phagocytosis of Alzheimer's disease-related amyloid- $\beta 42$ by human microglia and decrease inflammatory markers. J Alzheimers Dis 2013; 35(4):697-713. DOI:10.3233/JAD-130131

136. Moon D-O, Kim K-C, Jin C-Y, et al. Inhibitory effects of eicosapentaenoic acid on lipopolysaccharide-induced activation in BV2 microglia. Int Immunopharmacol 2007;7(2):222-229. DOI:10.1016/j.intimp.2006.10.001

137. Valdearcos M, Myers MG, Koliwad SK. Hypothalamic microglia as potential regulators of metabolic physiology. Nat Metab 2019;1(3):314-320. DOI:10.1038/s42255-0190040-0

138. Baufeld C, Osterloh A, Prokop S, Miller KR, Heppner FL. High-fat diet-induced brain region-specific phenotypic spectrum of CNS resident microglia. Acta Neuropathol (Berl) 2016; 132(3):361-375. DOI:10.1007/s00401016-1595-4

139. Baquedano E, Ruiz-Lopez AM, Sustarsic EG, et al. The Absence of GH Signaling Affects the Susceptibility to High-Fat Diet-Induced Hypothalamic Inflammation in Male Mice. Endocrinology 2014; 155(12):4856-4867. DOI:10.1210/ en.2014-1367

140. Butovsky O, Jedrychowski MP, Moore CS, et al. Identification of a unique TGF- $\beta$-dependent molecular and func- 
tional signature in microglia. Nat Neurosci 2014; 17(1):131143. DOI:10.1038/nn.3599

141. Gzielo K, Soltys Z, Rajfur Z, Setkowicz ZK. The Impact of the Ketogenic Diet on Glial Cells Morphology. A Quantitative Morphological Analysis. Neuroscience 2019; 413:239251. DOI:10.1016/j.neuroscience.2019.06.009

142. Masino SA, Rho JM. Mechanisms of ketogenic diet action. In: Noebels JL, Avoli M, Rogawski MA, Olsen RW, Delgado-Escueta AV, editors. Jasper's basic mechanisms of the epilepsies. 4th edition. Bethesda (MD): National Center for Biotechnology Information (US), 2012

143. Fann DY-W, Santro T, Manzanero S, et al. Intermittent fasting attenuates inflammasome activity in ischemic stroke. Exp Neurol 2014; 257:114-119. DOI:10.1016/j.expneurol.2014.04.017

144. Gasior M, Rogawski MA, Hartman AL. Neuroprotective and disease-modifying effects of the ketogenic diet: Behav Pharmacol 2006; 17(5-6):431-439. DOI:10.1097/00008877200609000-00009

145. Longo VD, Mattson MP. Fasting: Molecular Mechanisms and Clinical Applications. Cell Metab 2014; 19(2):181-192. DOI:10.1016/j.cmet.2013.12.008

146. Ghosh S, Castillo E, Frias ES, Swanson RA. Bioenergetic regulation of microglia. Glia 2018; 66(6):1200-1212. DOI:10.1002/glia.23271

147. Huang C, Wang P, Xu X, et al. The ketone body metabolite $\beta$-hydroxybutyrate induces an antidepression-associated ramification of microglia via HDACs inhibition-triggered Akt-small RhoGTPase activation. Glia 2018; 66(2):256278. DOI:10.1002/glia.23241

148. Youm Y-H, Nguyen KY, Grant RW, et al. The ketone metabolite $\beta$-hydroxybutyrate blocks NLRP3 inflammasomemediated inflammatory disease. Nat Med 2015; 21(3):263269. DOI:10.1038/nm.3804

149. Taggart AKP, Kero J, Gan X, et al. (d)- $\beta$-Hydroxybutyrate Inhibits Adipocyte Lipolysis via the Nicotinic Acid Receptor PUMA-G. J Biol Chem 2005; 280(29):26649-26652. DOI:10.1074/jbc.C500213200

150. Rahman M, Muhammad S, Khan MA, et al. The $\beta$-hydroxybutyrate receptor HCA2 activates a neuroprotective subset of macrophages. Nat Commun 2014; 5:3944. DOI:10.1038/ncomms4944

151. Newman JC, Verdin E. Ketone bodies as signaling metabolites. Trends Endocrinol Metab 2014; 25(1):42-52. DOI:10.1016/j.tem.2013.09.002

152. Fu S-P, Wang J-F, Xue W-J, et al. Anti-inflammatory effects of BHBA in both in vivo and in vitro Parkinson's disease models are mediated by GPR109A-dependent mecha- nisms. J Neuroinflammation 2015; 12(1):9. DOI:10.1186/ s12974-014-0230-3

153. Bianchi R, Giambanco I, Donato R. S100B/RAGE-dependent activation of microglia via NF- $\kappa \mathrm{B}$ and AP-1. Neurobiol Aging 2010; 31(4):665-677. DOI:10.1016/j.neurobiolaging.2008.05.017

154. Chen J, Sun Z, Jin M, et al. Inhibition of AGEs/RAGE/ Rho/ROCK pathway suppresses non-specific neuroinflammation by regulating BV2 microglial M1/M2 polarization through the NF- $\kappa \mathrm{B}$ pathway. J Neuroimmunol 2017; 305:108-114. DOI:10.1016/j.jneuroim.2017.02.010

155. Gruzdeva O, Borodkina D, Uchasova E, Dyleva Y, Barbarash O. Leptin resistance: underlying mechanisms and diagnosis. Diabetes Metab Syndr Obes Targets Ther 2019; 12:191-198. DOI:10.2147/DMSO.S182406

156. Rivest S. Editorial: Does Circulating Leptin Have the Ability to Cross the Blood-Brain Barrier and Target Neurons Directly? Endocrinology 2002; 143(9):3211-3213. DOI:10.1210/en.2002-220655

157. Farr OM, Gavrieli A, Mantzoros CS. Leptin applications in 2015: what have we learned about leptin and obesity? Curr Opin Endocrinol Diabetes Obes 2015; 22(5):353-359. DOI:10.1097/MED.0000000000000184

158. Sun Q, Jiang N, Sun R. Leptin signaling molecular actions and drug target in hepatocellular carcinoma. Drug Des Devel Ther 2014; 8:2295-302. DOI:10.2147/DDDT.S69004

159. Morioka T, Mori K, Motoyama K, Emoto M. Ectopic fat accumulation and glucose homeostasis: role of leptin in glucose and lipid metabolism and mass maintenance in skeletal muscle. In: Inaba M, editor. Musculoskeletal Disease Associated with Diabetes Mellitus. Tokyo: Springer Japan, 2016; 201-213.

160. Gao Y, Vidal-Itriago A, Milanova I, et al. Deficiency of leptin receptor in myeloid cells disrupts hypothalamic metabolic circuits and causes body weight increase. Mol Metab 2018; 7:155-160. DOI:10.1016/j.molmet.2017.11.003

161. Koga S, Kojima A, Ishikawa C, Kuwabara S, Arai K, Yoshiyama Y. Effects of diet-induced obesity and voluntary exercise in a tauopathy mouse model: Implications of persistent hyperleptinemia and enhanced astrocytic leptin receptor expression. Neurobiol Dis 2014; 71:180-192. DOI:10.1016/j. nbd.2014.08.015

162. Bouret SG. Formation of Projection Pathways from the Arcuate Nucleus of the Hypothalamus to Hypothalamic Regions Implicated in the Neural Control of Feeding Behavior in Mice. J Neurosci 2004; 24(11):2797-2805. DOI:10.1523/ JNEUROSCI.5369-03.2004

163. Loffreda S, et al. Leptin regulates proinflammatory im- 
mune responses. FASEB J 1998; 12: 57-65.

164. Arita Y, Kihara S, Ouchi N, et al. Paradoxical Decrease of an Adipose-Specific Protein, Adiponectin, in Obesity. Biochem Biophys Res Commun 1999; 257(1):79-83. DOI:10.1006/ bbrc. 1999.0255

165. Matsuzawa Y. Adiponectin: Identification, physiology and clinical relevance in metabolic and vascular disease. Atherosclerosis Suppl 2005; 6(2):7-14. DOI:10.1016/j.atherosclerosissup.2005.02.003

166. Kadowaki T, Yamauchi T. Adiponectin and Adiponectin Receptors. Endocr Rev 2005; 26(3):439-451. DOI:10.1210/ er.2005-0005

167. Nicolas S, Cazareth J, Zarif H, et al. Globular Adiponectin Limits Microglia Pro-Inflammatory Phenotype through an AdipoR1/NF- $\kappa B$ Signaling Pathway. Front Cell Neurosci 2017; 11:352. DOI:10.3389/fncel.2017.00352

168. Maeda N, Shimomura I, Kishida K, et al. Diet-induced insulin resistance in mice lacking adiponectin/ACRP30. Nat Med 2002; 8(7):731-737. DOI:10.1038/nm724

169. Xu A, Wang Y, Keshaw H, Xu LY, Lam KSL, Cooper GJS. The fat-derived hormone adiponectin alleviates alcoholic and nonalcoholic fatty liver diseases in mice. J Clin Invest 2003; 112(1):10. DOI:10.1172/JCI17797

170. Yamauchi T, Kamon J, Ito Y, et al. Cloning of adiponectin receptors that mediate antidiabetic metabolic effects. $\mathrm{Na}$ ture 2003; 423(6941):762-769. DOI:10.1038/nature01705

171. Yamauchi T, Nio Y, Maki T, et al. Targeted disruption of AdipoR1 and AdipoR2 causes abrogation of adiponectin binding and metabolic actions. Nat Med 2007; 13(3):332339. DOI:10.1038/nm1557

172. Liu J, Guo M, Zhang D, et al. Adiponectin is critical in determining susceptibility to depressive behaviors and has antidepressant-like activity. Proc Natl Acad Sci USA 2012; 109(30):12248-12253. DOI:10.1073/pnas.1202835109

173. Ouchi N, Walsh K. Adiponectin as an anti-inflammatory factor. Clin Chim Acta 2007; 380(1-2):24-30. DOI:10.1016/j. cca.2007.01.026

174. Chabry J, Nicolas S, Cazareth J, et al. Enriched environment decreases microglia and brain macrophages inflammatory phenotypes through adiponectin-dependent mechanisms: Relevance to depressive-like behavior. Brain Behav Immun 2015; 50:275-287. DOI:10.1016/j.bbi.2015.07.018

175. Gimble JM, Katz AJ, Bunnell BA. Adipose-derived stem cells for regenerative medicine. Circ Res 2007; 100(9):12491260. DOI:10.1161/01.RES.0000265074.83288.09

176. Stoker T, Blair N, Barker R. Neural grafting for Parkinson's disease: challenges and prospects. Neural Regen Res 2017; 12(3):389. DOI:10.4103/1673-5374.202935
177. Fraser JK, Wulur I, Alfonso Z, Hedrick MH. Fat tissue: an underappreciated source of stem cells for biotechnology. Trends Biotechnol 2006; 24(4):150-154. DOI:10.1016/j. tibtech.2006.01.010

178. Huang S-J, Fu R-H, Shyu W-C, et al. Adipose-Derived Stem Cells: Isolation, Characterization, and Differentiation Potential. Cell Transplant 2013; 22(4):701-709. DOI:10.3727/096368912X655127

179. Zuk PA, Zhu M, Ashjian P, et al. Human Adipose Tissue Is a Source of Multipotent Stem Cells. Mol Biol Cell 2002; 12:4279-95. DOI:10.1091/mbc.e02-02-0105

180. Dazzi F, Lopes L, Weng L. Mesenchymal stromal cells: a key player in 'innate tolerance'? Immunology 2012; 137(3):206213. DOI:10.1111/j.1365-2567.2012.03621.x

181. English K, Mahon BP. Allogeneic mesenchymal stem cells: Agents of immune modulation. J Cell Biochem 2011;112(8):1963-1968. DOI:10.1002/jcb.23119

182. Thakur RS, Tousif S, Awasthi V, et al. Mesenchymal stem cells play an important role in host protective immune responses against malaria by modulating regulatory $\mathrm{T}$ cells: Immunity to infection. Eur J Immunol 2013; 43(8):20702077. DOI:10.1002/eji.201242882

183. Schwartz MW, Woods SC, Porte D, Seeley RJ, Baskin DG. Central nervous system control of food intake. Nature 2000; 404(6778):661-671. DOI:10.1038/35007534

184. Velloso LA, Schwartz MW. Altered hypothalamic function in diet-induced obesity. Int J Obes 2011; 35(12):1455-1465. DOI:10.1038/ijo.2011.56

185. Buckman LB, Hasty AH, Flaherty DK, et al. Obesity induced by a high-fat diet is associated with increased immune cell entry into the central nervous system. Brain Behav Immun 2014; 35:33-42. DOI:10.1016/j.bbi.2013.06.007

186. Valdearcos M, Douglass JD, Robblee MM, et al. Microglial Inflammatory Signaling Orchestrates the Hypothalamic Immune Response to Dietary Excess and Mediates Obesity Susceptibility. Cell Metab 2017; 26(1):185-197.e3. DOI:10.1016/j.cmet.2017.05.015

187. Yi C-X, Walter M, Gao Y, et al. TNFa drives mitochondrial stress in POMC neurons in obesity. Nat Commun 2017; 8:15143. DOI:10.1038/ncomms15143

188. Pinto S. Rapid Rewiring of Arcuate Nucleus Feeding Circuits by Leptin. Science 2004; 304(5667):110-115. DOI:10.1126/science.1089459

189. Horvath TL, Sarman B, Garcia-Caceres C, et al. Synaptic input organization of the melanocortin system predicts diet-induced hypothalamic reactive gliosis and obesity. Proc Natl Acad Sci 2010; 107(33):14875-14880. DOI:10.1073/ pnas. 1004282107 
190. De Luca SN, Sominsky L, Soch A, et al. Conditional microglial depletion in rats leads to reversible anorexia and weight loss by disrupting gustatory circuitry. Brain Behav Immun 2019; 77:77-91. DOI:10.1016/j.bbi.2018.12.008

191. André C, Guzman-Quevedo O, Rey C, et al. Inhibiting Microglia Expansion Prevents Diet-Induced Hypothalamic and Peripheral Inflammation. Diabetes 2017; 66(4):908919. DOI:10.2337/db16-0586

192. Barreto-Vianna ARC, Aguila MB, Mandarim-de-Lacerda CA. Effects of liraglutide in hypothalamic arcuate nucleus of obese mice: Beneficial Central Effects of Liraglutide. Obesity 2016; 24(3):626-633. DOI:10.1002/oby.21387

193. Naznin F, Sakoda H, Okada T, et al. Canagliflozin, a sodium glucose cotransporter 2 inhibitor, attenuates obesityinduced inflammation in the nodose ganglion, hypothalamus, and skeletal muscle of mice. Eur J Pharmacol 2017; 794:37-44. DOI:10.1016/j.ejphar.2016.11.028

194. Steculorum SM, Vogt MC, Brüning JC. Perinatal Programming of Metabolic Diseases. Endocrinol Metab Clin North Am 2013; 42(1):149-164. DOI:10.1016/j.ecl.2012.10.002

195. Sullivan EL, Grove KL. Metabolic Imprinting in Obesity. In: Langhans W, Geary N, eds. Forum of Nutrition. Vol 63. Basel: KARGER, 2009; 186-194. DOI:10.1159/000264406

196. Vogt MC, Paeger L, Hess S, et al. Neonatal Insulin Action Impairs Hypothalamic Neurocircuit Formation in Response to Maternal High-Fat Feeding. Cell 2014; 156(3):495-509. DOI:10.1016/j.cell.2014.01.008

197. Howie GJ, Sloboda DM, Kamal T, Vickers MH. Maternal nutritional history predicts obesity in adult offspring independent of postnatal diet: Maternal high fat nutrition and obesity in offspring. J Physiol 2009; 587(4):905-915.
DOI:10.1113/jphysiol.2008.163477

198. Parlee SD, MacDougald OA. Maternal nutrition and risk of obesity in offspring: The Trojan horse of developmental plasticity. Biochim Biophys Acta BBA - Mol Basis Dis 2014; 1842(3):495-506. DOI:10.1016/j.bbadis.2013.07.007

199. Gertler A. Role of leptin in early metabolic programming. Adipobiology 2009; 1(0):27. DOI:10.14748/adipo.v1.247

200. Bilbo SD, Tsang V. Enduring consequences of maternal obesity for brain inflammation and behavior of offspring. FASEB J 2010; 24(6):2104-2115. DOI:10.1096/fj.09-144014

201. Rother E, Kuschewski R, Alcazar MAA, et al. Hypothalamic JNK1 and IKK $\beta$ Activation and Impaired Early Postnatal Glucose Metabolism after Maternal Perinatal High-Fat Feeding. Endocrinology 2012; 153(2):770-781. DOI:10.1210/en.2011-1589

202. Sullivan EL, Grayson B, Takahashi D, et al. Chronic Consumption of a High-Fat Diet during Pregnancy Causes Perturbations in the Serotonergic System and Increased Anxiety-Like Behavior in Nonhuman Primate Offspring. $J$ Neurosci 2010; 30(10):3826-3830. DOI:10.1523/JNEUROSCI.5560-09.2010

203. Kang SS, Kurti A, Fair DA, Fryer JD. Dietary intervention rescues maternal obesity induced behavior deficits and neuroinflammation in offspring. J Neuroinflam 2014; 11:156. DOI:10.1186/s12974-014-0156-9

204. Maldonado-Ruiz R, Cárdenas-Tueme M, Montalvo-Martínez L, et al. Priming of hypothalamic ghrelin signaling and microglia activation exacerbate feeding in rats' offspring following maternal overnutrition. Nutrients 2019; 11(6):1241. DOI:10.3390/nu11061241 